\title{
Do Patients Drink Enough Water? Actual Pure Water Intake Compared to the Theoretical Daily Rules of Drinking Eight 8-Ounce Glasses and Drinking Half Your Body Weight in Ounces
}

\author{
Paul A. Oakley, Melissa L. Baird \\ Private Practice, Newmarket, Ontario, Canada \\ Email: docoakley.icc@gmail.com
}

Received 3 July 2015; accepted 25 July 2015; published 28 July 2015

Copyright (C) 2015 by authors and Scientific Research Publishing Inc.

This work is licensed under the Creative Commons Attribution International License (CC BY).

http://creativecommons.org/licenses/by/4.0/

(c) (i) Open Access

\begin{abstract}
Water is vital for virtually every bodily process, but many people don't drink enough water. We assessed how much actual water, on average, was drank by 100 consecutive patients from a wellness clinic. The average water intake was about five 8-ounce glasses of water a day. When compared to the "drink eight glasses of water a day" rule, our sample was 3 glasses short. When compared to the "drink half your body weight in ounces" rule, our sample was 6 glasses short. Chronic, unintentional dehydration is so common that it may be better to consider many "dehydration diseases" such as asthma and allergies as well as non-infectious conditions and chronic pains to be identified as "indicators of body thirst" and not the conditions that today are considered "diseases of unknown etiology". Physiologically there are parameters of dehydration that can be measured prior to one feeling "thirsty", and therefore, simply drinking "ad libitum" or by natural instinct may not be adequate. Patients need to be told to drink more water and to keep a mental daily tally to be sure to optimize their hydration status to better their health.
\end{abstract}

\section{Keywords}

Water, Hydration, Dehydration, Drinking, Euhydration

\section{Introduction}

Water is vital for virtually every bodily process [1]-[4] and water consumption needs to occur on a daily basis as

How to cite this paper: Oakley, P.A. and Baird, M.L. (2015) Do Patients Drink Enough Water? Actual Pure Water Intake Compared to the Theoretical Daily Rules of Drinking Eight 8-Ounce Glasses and Drinking Half Your Body Weight in Ounces. Journal of Water Resource and Protection, 7, 883-887. http://dx.doi.org/10.4236/jwarp.2015.711072 
its absence will result in death within only days [5]. Despite the great importance of daily water consumption, a great percentage of the population do not drink enough; in fact, estimates suggest that $75 \%$ of us do not drink enough water [6]! The possible effect of chronic dehydration on health is not fully understood [3] but is of primordial importance to optimizing health.

Chronic, unintentional dehydration is so common that Dr. Batmanghelidj [7] considers many "dehydration diseases" such as asthma and allergies as well as non-infectious conditions and chronic pains to be identified as "indicators of body thirst" and not the conditions that today are considered "diseases of unknown etiology".

Subtle, chronic, unintentional dehydration may affect one's health in a plethora of ways. Changes in thermoregulatory response to exercise occur with as little as $1 \%$ loss of body weight by dehydration [8]. With 2-3\% dehydration loss of body weight, cognitive [9]-[12] and physical performance [13]-[15] are both impaired.

Water intake has also been directly linked to specific diseases. A lack of water intake, for example, is associated with headaches [16], increased risk of bladder cancer in men [17], as well as women [18], increased risk of colorectal cancer and premalignant adenomatous polyps [19]-[21], increased risk of fatal coronary heart disease [22], and also increased likelihood of mortality in the hospitalized elderly [23] [24].

Ironically, water intake and its effects on health have been studied little, and in a recent and thorough review Popkin states: "We do not truly understand how hydration affects health and well-being, even the impact of water intakes on chronic diseases [3]."

The old adage, "drink eight glasses of water a day" ("8 $\times 8$ ") has no scientific merit [25]. How can a $100 \mathrm{lb}$ female and a $250 \mathrm{lb}$ male have the same water requirements? A more realistic recommendation is to "drink half your body weight in ounces" (" $1 / 2 \mathrm{BW}$ "). This would translate into the $100 \mathrm{lb}$ female needing to drink 6.25 glasses of water a day, and the $250 \mathrm{lb}$ male needing to drink 15.6 glasses of water a day, which from a logical standpoint seems reasonable.

The purpose of the present study was to assess how much water patients from a wellness clinic actually drank. Second, we wanted to compare the actual water drank to the rule of $8 \times 8$ as well as to the more idealized rule of $1 / 2 \mathrm{BW}$.

\section{Methods}

Retrospectively, from a wellness practice in Newmarket, Ontario, Canada, 100 consecutive patient files were reviewed to retrieve the patient's demographics as well as reported daily water consumption. One hundred patients were chosen due to being a sufficient representative sample.

The data was gathered for three consecutive months, from all new patients presenting to our wellness clinic, for various reasons, dating from February 1, 2015 - April 30, 2015. If any data were missing, an attempt was made to contact the patient to complete the information. If the patient information was unattainable, the subject was not included for study.

\section{Results}

There were 51 females and 49 males included in the study (Table 1). The average age was $50( \pm 13.7)$, average height was $1.7 \mathrm{~m}( \pm 0.1)$, average weight was $80.9 \mathrm{~kg}( \pm 19.4)$, or in pounds $178.3( \pm 42.7)$. The average BMI was $27.8( \pm 5.3)$.

On average our sample drank $4.9( \pm 3.7)$ glasses of water a day. The range of water drinking was large and ranged from 0 to 19, 8-ounce glasses of water per day. When calculating the theoretical glasses of water a day based on half body weight, it was determined that on average, the sample should be consuming $11.1( \pm 2.7)$ glasses of water, although again the range varied greatly from 6.9 to 21.6 glasses a day for the lightest patient at $110 \mathrm{lbs}$ to the heaviest patient at $345 \mathrm{lbs}$.

Table 2 shows the number of patients and percentage of the sample size per different amounts of water drinking. As shown, $51 \%$ of our sample drank 4 or less glasses of water per day. Five percent of the sample did not drink water at all.

\section{Discussion}

We assessed how much water a consecutive sample of 100 chiropractic patients drank on a daily basis from a wellness clinic. This was determined to be 4.9 - 8 oz. glasses a day. Even if the old adage of drinking 8 glasses 
Table 1. Demographics, water consumption data, as well as theoretical calculation of water deficit based on $8 \times 8$ and 1/2BW on 100 consecutive chiropractic patients.

\begin{tabular}{|c|c|c|c|c|c|c|c|c|c|}
\hline Sex & Age & ht & wt & bmi & $\mathrm{H} 2 \mathrm{O} / \mathrm{d}$ & $" 8 \times 8 "$ & Diff & "1/2BW" & Diff \\
\hline $\mathrm{F}(51)$ & $\begin{array}{c}49.7 \mathrm{yrs} \\
(13.2)\end{array}$ & $\begin{array}{c}1.6 \mathrm{~m} \\
(0.1)\end{array}$ & $\begin{array}{c}71.0 \mathrm{~kg} \\
(14.3)\end{array}$ & $\begin{array}{l}26.6 \\
(5.1)\end{array}$ & $\begin{array}{c}4.4 \\
(2.9)\end{array}$ & 8 & $\begin{array}{l}-3.6 \\
(2.9)\end{array}$ & $\begin{array}{c}9.8 \\
(2.0)\end{array}$ & $\begin{array}{l}-5.4 \\
(3.6)\end{array}$ \\
\hline M (49) & $\begin{array}{c}50.3 \mathrm{yrs} \\
(14.3)\end{array}$ & $\begin{array}{c}1.8 \mathrm{~m} \\
(0.1)\end{array}$ & $\begin{array}{c}91.2 \mathrm{~kg} \\
(18.8)\end{array}$ & $\begin{array}{l}29.1 \\
(5.3)\end{array}$ & $\begin{array}{c}5.5 \\
(4.2)\end{array}$ & 8 & $\begin{array}{l}-2.5 \\
(4.2)\end{array}$ & $\begin{array}{l}12.6 \\
(2.6)\end{array}$ & $\begin{array}{l}-7.1 \\
(4.8)\end{array}$ \\
\hline Total (100) & $\begin{array}{l}50 \text { yrs } \\
(13.7)\end{array}$ & $\begin{array}{c}1.7 \mathrm{~m} \\
(0.1)\end{array}$ & $\begin{array}{c}80.9 \mathrm{~kg} \\
(19.4)\end{array}$ & $\begin{array}{l}27.8 \\
(5.3)\end{array}$ & $\begin{array}{c}4.9 \\
(3.7)\end{array}$ & 8 & $\begin{array}{l}-3.1 \\
(3.7)\end{array}$ & $\begin{array}{l}11.1 \\
(2.7)\end{array}$ & $\begin{array}{l}-6.2 \\
(4.3)\end{array}$ \\
\hline
\end{tabular}

Presented as average with standard deviations (). "1/2BW" = Number of 8-ounce glasses of water calculated by dividing bodyweight in pounds by two, then dividing by 8 . "Diff" = difference between actual water consumption (H2O/d) and $8 \times 8$ or $1 / 2 \mathrm{BW}$.

Table 2. Number of patients, sample and cumulative percentage in the 100 sample size by the number of 8 oz. glasses of $\mathrm{H}_{2} \mathrm{O}$ per day.

\begin{tabular}{cccc}
\hline No. 8 oz $\mathrm{H}_{2} \mathrm{O}$ /day & $\mathrm{n}$ & Sample $\%$ & Cumulative \% \\
\hline 0 & 5 & $5 \%$ & $5 \%$ \\
$1-2$ & 26 & $26 \%$ & $31 \%$ \\
$3-4$ & 20 & $20 \%$ & $51 \%$ \\
$5-6$ & 23 & $23 \%$ & $74 \%$ \\
$7-8$ & 11 & $11 \%$ & $85 \%$ \\
$9-10$ & 6 & $5 \%$ & $91 \%$ \\
$11-12$ & 5 & $4 \%$ & $96 \%$ \\
\hline
\end{tabular}

of water a day were scientifically verified, which it is not [25], most of our patients would be well deficient.

When we assessed how much water our patients should be drinking based on the theoretical rule of drinking half your body weight in ounces, we determined that most patients were again deficient, but even more so then going by the 8 glasses a day rule. On average, our sample was 6 glasses short of making their daily requirements based on the half body weight assumption.

The results may be quite alarming considering many patients drank little to no water a day. For example, 36\% of our sample drank 2 or less glasses of water a day (Table 2). Even under sedentary conditions the body may require $0.3 \mathrm{~L}$ per hour; even more, under extreme heat and/or exercise the body may lose and therefore require many liters of water in a single day [26] [27].

Critics of drinking extra water, beyond that from being thirsty often suggest that people will drink as much as they need, as the perception of thirst will guide their intake [25] [28]. However, physiologically, there are body indicators suggesting dehydrating effects have occurred before the feeling of thirst is perceived. For example, in a thorough review by Maughan et al. [29] they concluded that: "Indicators such as a reduction in urine output and failure to maintain body mass are more reliable measures of dehydration than the feeling of thirst.” Coupled with the fact that healthy individuals can well tolerate a reduction of water volume of up to 5-10\% of body weight at rest [8], the reliance on waiting to feel thirsty is definitely not an ideal way to guide water intake, as our results suggest, and patients should consciously monitor their water intake on a daily basis to meet their euhydration goal.

What is the euhydration goal? As we suggested earlier, we believe the guideline of drinking half body weight in ounces would be more hydrating than the 8 glasses a day rule. Just as the $8 \times 8$ rule has unknown precise origins [25], the half body weight rule also has unknown origins, let alone being scientifically validated (we were unable to locate any documentation). There may be concerns, however, for the $1 / 2 \mathrm{BW}$ rule when it comes to larger massed individuals. One patient in our sample weighed $345 \mathrm{lbs}$, therefore, according to the 1/2BW rule he would need 21.6 glasses of water a day-intuitively this seems excessive. 
Since larger individuals have a much larger body mass percentage being fat, the 1/2BW rule may be over-estimating for increasing body masses. This concern needs to be scientifically verified. Alternatively, there is evidence of greater water drinking resulting in weight loss [7] [30]. If an obese person consumes high amounts of water according to the $1 / 2 \mathrm{BW}$ rule, this should reduce their weight, and in turn lead to a reduced water need according to the $1 / 2 \mathrm{BW}$ rule-an unforeseen advantage for greater massed individuals.

There are obvious limitations to the current study. First, we do not account for water intake resulting from foods, this has been approximated as about 20 percent [31]. Nor have we accounted for caffeinated and alcoholic beverages that cause a net water reduction as both act as diuretics [32]. The patients relied on recall, simply remembering, on average how much water they consumed, potentially leading to inaccurate estimates for some individuals. Finally, and again due to memory recall, fluid intake can vary dramatically from day to day, so pinpointing an average consumption without measuring actual intake may be inaccurate.

Herein we discussed dehydration in terms of "free water deficit", or the lack of fluid intake. There is also dehydration in terms of sodium depletion [33]; this involves both water and sodium depletion. Sodium intake, physiologically, is just as important as water intake and cannot be forgotten as water's vital companion nutrient.

\section{Conclusion}

The majority of our sample did not drink enough water, whether going by the $8 \times 8$ or the $1 / 2 \mathrm{BW}$ rule of thumb. On average patients were 3 - 6 glasses short of ingesting an ideal water volume. Some patients don't drink water. Patients need to be told to make a conscious effort to drink more water.

\section{References}

[1] Weitzman, R.E. and Kleeman, C.R. (1979) The Clinical Physiology of Water Metabolism. Part I. The Physiologic Regulation of Arginine Vasopressin Secretion and Thirst. Western Journal of Medicine, 131, 373-400.

[2] Marcos, A., Manonelles, P., Palacios, N., et al. (2014) Physical Activity, Hydration and Health. Nutricion Hospitalaria, 9, 1224-1239.

[3] Popkin, B.M., D’Anci, K.E. and Rosenberg, I.H. (2010) Water, Hydration and Health. Nutrition Reviews, 68, $439-458$. http://dx.doi.org/10.1111/j.1753-4887.2010.00304.x

[4] Guyton, A.C. and Hall, J.E. (2000) Textbook of Medical Physiology. WB Saunders Co., Philadelphia.

[5] Brown, A.H. (1947) Survival without Drinking Water in the Desert. In: Adolph, E.F., Ed., Physiology of Man in the Desert, Interscience, New York, 271-279.

[6] Ericson, J. (2013) 75\% of Americans May Suffer from Chronic Dehydration, According to Doctors. http://www.medicaldaily.com/75-americans-may-suffer-chronic-dehydration-according-doctors-247393

[7] Batmanghelidj, F. (2008) Your Body’s Many Cries for Water. 3rd Edition, Global Health Solutions, VA.

[8] Sawka, M.N. and Pandolf, K.B. (1990) Effects of Body Water Loss on Physiological Function and Exercise Performance. In: Gisolfi, C.V. and Lamb, D.R., Eds., Fluid Homeostasis during Exercise, Benchmark Press, Carmel, 1-38.

[9] Cian, C., Barraud, P.A., Melin, B. and Raphel, C. (2001) Effects of Fluid Ingestion on Cognitive Function after Heat Stress of Exercise-Induced Dehydration. International Journal of Psychophysiology, 42, 243-251. http://dx.doi.org/10.1016/S0167-8760(01)00142-8

[10] Gopinathan, P.M., Pichan, G. and Sharma, V.M. (1988) Role of Dehydration in Heat Stress-Induced Variations in Mental Performance. Archives of Environmental \& Occupational Health, 43, $15-17$. http://dx.doi.org/10.1080/00039896.1988.9934367

[11] Sharma, V.M., Sridharan, K., Pichan, G. and Panwar, M.R. (1986) Influence of Heat Stress-Induced Dehydration on Mental Functions. Ergonomics, 29, 791-799. http://dx.doi.org/10.1080/00140138608968315

[12] Lindseth, P.D., Lindseth, G.N., Petros, T.V., Jensen, W.C. and Caspers, J. (2013) Effects of Hydration on Cognitive Function of Pilots. Military Medicine, 178, 792-798. http://dx.doi.org/10.7205/MILMED-D-13-00013

[13] Armstrong, L.E., Costill, D.L. and Fink, W.J. (1985) Influence of Diuretic-Induced Dehydration on Competitive Running Performance. Medicine \& Science in Sports \& Exercise, 17, 456-461. http://dx.doi.org/10.1249/00005768-198508000-00009

[14] Murray, B. (2007) Hydration and Physical Performance. Journal of the American College of Nutrition, 26, 542S-548S.

[15] Cheuvront, S.N., Montain, S.J. and Sawka, M.N. (2007) Fluid Replacement and Performance during the Marathon. Sports Medicine, 37, 353-357. http://dx.doi.org/10.2165/00007256-200737040-00020

[16] Sherriffs, S.M., Merson, S.J., Fraser, S.M. and Archer, D.T. (2004) The Effects of Fluid Restriction on Hydration Sta- 
tus and Subjective Feelings in Man. British Journal of Nutrition, 91, 951-958. http://dx.doi.org/10.1079/BJN20041149

[17] Michaud, D.S., Spiegelman, D., Clinton, S.K., Rimm, E.B., Curhan, G.C., Willett, W.C. and Giovannucci, E.L. (1999) Fluid Intake and the Risk of Bladder Cancer in Men. The New England Journal of Medicine, 340, 1390-1397. http://dx.doi.org/10.1056/NEJM199905063401803

[18] Zhou, J., Kelsey, K.T., Giovannucci, E. and Michaud, D.S. (2014) Fluid Intake and Risk of Bladder Cancer in the Nurses' Health Studies. International Journal of Cancer, 135, 1229-1237. http://dx.doi.org/10.1002/ijc.28764

[19] Lubin, F., Rozen, P., Arieli, B., Farbstein, M., Knaani, Y., Bat, L. and Farbstein, H. (1997) Nutritional and Lifestyle Habits and Water-Fiber Interaction in Colorectal Adenoma Etiology. Cancer Epidemiology, Biomarkers \& Prevention, 6, 79-85.

[20] Shannon, J., White, E., Shattuck, A.L. and Potter, J.D. (1996) Relationship of Food Groups and Water Intake to Colon Cancer Risk. Cancer Epidemiology, Biomarkers \& Prevention, 5, 495-502.

[21] Tang, R., Wang, J.Y., Lo, S.K. and Hsieh, L.L. (1999) Physical Activity, Water Intake and Risk of Colorectal Cancer in Taiwan: A Hospital-Based Case-Control Study. International Journal of Cancer, 82, 484-489. http://dx.doi.org/10.1002/(sici)1097-0215(19990812)82:4<484::aid-ijc3>3.0.c0;2-a

[22] Chan, J., Knutsen, S.F., Blix, G.G., Lee, J.W. and Fraser, G.E. (2002) Water, Other Fluids, and Fatal Coronary Heart Disease: The Adventist Health Study. American Journal of Epidemiology, 155, 827-833. http://dx.doi.org/10.1093/aje/155.9.827

[23] Himelstein, D., Jones, A. and Woolhandler, S. (1983) Hypernatremic Dehydration in Nursing Home Patients: An Indicator of Neglect. Journal of the American Geriatrics Society, 31, 466-471. http://dx.doi.org/10.1111/j.1532-5415.1983.tb05118.x

[24] Mahowald, J. and Himmelstein, D. (1981) Hypernatremia in the Elderly: Relation to Infection and Mortality. Journal of the American Geriatrics Society, 29, 177-180. http://dx.doi.org/10.1111/j.1532-5415.1981.tb01761.x

[25] Valtin, H. (2002) “Drink at Least Eight Glasses of Water a Day.” Really? Is There Scientific Evidence for "8 $\times$ 8”? American Journal of Physiology-Regulatory, Integrative and Comparative Physiology, 283, R993-R1004. http://dx.doi.org/10.1152/ajpregu.00365.2002

[26] Sawka, M.N., Latzka, W.A., Matott, R.P. and Montain, S.J. (1998) Hydration Effects on Temperature Regulation. International Journal of Sports Medicine, 19, S108-S110. http://dx.doi.org/10.1055/s-2007-971971

[27] Sawka, M.N., Cheuvront, S.N. and Carter, R. (2005) Human Water Needs. Nutrition Reviews, 63, S30-S39. http://dx.doi.org/10.1301/nr.2005.jun.S30-S39

[28] Negoianu, D. and Goldfarb, S. (2008) Just Add Water. Journal of the American Society of Nephrology, 19, $1041-1043$. http://dx.doi.org/10.1681/ASN.2008030274

[29] Maughan, R.J., Leiper, J.B. and Shirreffs, S.M. (1997) Factors Influencing the Restoration of Fluid and Electrolyte Balance after Exercise in the Heat. British Journal of Sports Medicine, 31, 175-182. http://dx.doi.org/10.1136/bjsm.31.3.175

[30] Stookey, J.D. (2001) Energy Density, Energy Intake and Weight Status in a Large Free-Living Sample of Chinese Adults: Exploring the Underlying Roles of Fat, protein, Carbohydrate, Fiber and Water Intakes. European Journal of Clinical Nutrition, 55, 349-359. http://dx.doi.org/10.1038/sj.ejcn.1601163

[31] Ershow, A.G. and Cantor, K.P. (1989) Total Water and Tapwater Intake in the United States: Population-Based Estimates of Quantities and Sources. FASEB/LSRO, Bethesda.

[32] Hines, D. (2001) The Power of $\mathrm{H}_{2} \mathrm{O}$. Am Fitness, 19, 23-25.

[33] Leaf, A. (1984) Dehydration in the Elderly. The New England Journal of Medicine, 311, 791-792. http://dx.doi.org/10.1056/NEJM198409203111209 